\title{
Critical aspects of social networks in a resettlement setting
}

By: A.J. Faas, Eric C. Jones, Graham A. Tobin, Linda M. Whiteford, Arthur D. Murphy

Faas, A.J. Jones, E.C., Tobin, G.A., Whiteford, L.M. \& Murphy, A.D. (2015). Critical aspects of social networks in a resettlement setting. Development in Practice, 25(2), 221-233. doi: $10.1080 / 09614524.2015 .1000827$

This is an Accepted Manuscript of an article published by Taylor \& Francis in

Development in Practice on 12 Mar 2015, available online: http://wwww.tandfonline.com/10.1080/09614524.2015.1000827.

***@) Taylor \& Francis. Reprinted with permission. No further reproduction is authorized without written permission from Taylor \& Francis. This version of the document is not the version of record. Figures and/or pictures may be missing from this format of the document. $* * *$

\section{Abstract:}

Each year, more than 30 million people worldwide are displaced by disaster, development, and conflict. The sheer magnitude of displacement points to a need for wider application of social science theories and methodologies to the special problems posed by these crises. We are convinced that social network analysis of the structure and development of social relations can help to identify variables and patterns essential to maintaining or fostering social (re)articulation in resettlement. The research model we propose applies advances in network methodology to emerging theory on structural gaps in networks in the context of forced displacement and resettlement.

Chaque année, plus de 30 millions de personnes de par le monde sont déplacées par des catastrophes, le développement et les conflits. L'ampleur même du déplacement indique la nécessité d'appliquer de façon plus large les théories et les méthodologies des sciences sociales aux problèmes spéciaux soulevés par ces crises. Nous avons la conviction qu'une analyse basée sur les réseaux sociaux de la structure et du développement des relations sociales peut contribuer à identifier des variables et des schémas essentiels pour maintenir ou favoriser une (ré)articulation sociale dans le contexte de la réinstallation. le modèle de recherche que nous proposons applique les progrès réalisés en méthodologie des réseaux aux théories émergentes sur les lacunes structurelles des réseaux, ce dans le contexte du déplacement et de la réinstallation forcés.

Todos los años, a nivel mundial, más de 30 millones de personas son desplazadas como consecuencia de desastres, planes de desarrollo o conflictos. La enorme magnitud que tiene dicho desplazamiento da cuenta de la necesidad de aplicar más ampliamente las teorías y las metodologías propias de las ciencias sociales a los problemas idiosincráticos surgidos de estas 
crisis. Los autores sostienen que un análisis de la estructura y el desarrollo de las relaciones sociales realizado a partir de las redes sociales, puede ayudar a identificar variables y patrones esenciales con el objetivo de mantener o fomentar la (re)articulación social en los nuevos asentamientos de desplazados. En este sentido, los autores proponen un modelo de investigación que aplica los avances logrados en la metodología de redes a la teoría emergente sobre las lagunas estructurales que se detectan en las redes en contextos de desplazamiento involuntario y de reasentamiento.

Keywords: Conflict and reconstruction | Forced displacement | Labour and livelihoods | Migration Aid | Aid effectiveness | Latin America and the Caribbean

\section{Article:}

\section{Introduction}

It may seem odd or belated to argue for a social networks approach to research and policy in forced displacement and resettlement, where the concept of social networks has been invoked for nearly two decades in applied research as a way to foster the development of resettlement policies intended to avoid destroying resettlers' social capital. However, social network analysis has not been applied to a resettlement setting. Thus, this article aims to present results produced by network analysis we performed in disaster-induced resettlements. Our findings are less consistent than are the previous theoretical models or policy prescriptions in the field of resettlement based upon social network concepts. We hope to build upon the resettlement and development policy prescriptions that draw upon social networks - largely metaphorically - by critically and empirically evaluating key network principles in the context of disaster-induced resettlements in highland Ecuador.

\section{Research sites}

Our study took place in two disaster-induced resettlements in the central Andean highlands of Ecuador. In the wake of the devastating eruptions of the stratovolcano Mt Tungurahua in 1999 and 2006, several agencies constructed resettlements for those displaced. The first resettlement, Penipe Nuevo, was built in the city of Penipe that previously had around 150 homes. The 287 new homes were built close together (approximately $5000 \mathrm{ft}^{2}$ lots) on an urban grid with three to five total rooms each. Of these new homes, 185 were constructed by the Ministry of Housing and Urban Development (Ministerio de Desarollo Urbano y Vivienda, or MIDUVI) and 102 were constructed by the US-based Christian Evangelical disaster relief organisation, Samaritan's Purse. Resettlers were grouped together into homes in blocks that corresponded to their villages of origin, although some village groups were split into two spatial cohorts between the MIDUVI and Samaritan's Purse homes. Also, prior villages did not fit perfectly into each block, so some blocks had people from more than one village. Roughly six kilometres to the southeast of Penipe, the Ecuadorian NGO Fundacion Esquel constructed 45 homes in two concentric rectangles around a central park and granted roughly one hectare of land to each resettler household. In the 
larger, more urban, resettlement of Penipe, resettlers' primary economic recourse was to continue sowing crops on their land at the base of the still active volcano, although the soil's productive capacity was severely reduced by ashfall and each new wave of ashfall destroyed much or all of what did grow. Because the smaller rural resettlement of Pusuca included parcels of land for all beneficiaries, almost all resettlers grew food and/or kept animals locally additionally, many people from both villages continued to tend animals and crops up on the volcano at their prior lands.

\section{Literature review}

The concept of the social network is virtually ubiquitous in social science studies of resettlement in large part because of its perceived utility in explaining such critical phenomena as social support, institutional support, control and access of scarce resources, economic strategies, competition, cooperation, dependency, and cultural constructs and the patterned expression of symbols. Perhaps the earliest and most pervasive network concept in resettlement is the notion of the close-knit social network. Anthropological development perspectives typically accord explanatory weight to kin and ritual relations. The most common prescriptions associated with this literature are maintaining "tightly-knit kin groups" and already established "integrated communities" (Cernea 1996, 305) where individuals interact over common interests (Cernea 1997, 1575). These are seen as sustaining cultural integrity and generally equitable relations in the exchange of labour and material for agricultural production or goods and services in order to cope with the scarcity and isolation of poverty in the resettlement context. Indeed, these authors present more than sufficient evidence to demonstrate that the stress of resettlement is mitigated by clinging to familiar practices and relations of shared identity and mutual obligation in order to manage the risks of cultural and economic survival. And yet, in the same body of displacement literature, there are descriptions of latent conflict, weakened alliances, exploitation, opportunism, and resistance to established social hierarchies in otherwise integrated communities (Faas, 2012; Behura and Nayak 1993; Cernea 2003). Social actors variously resist change by closing off networks in order to pool or usurp scarce resources, by withdrawing resource inputs that they control, or by claiming greater remuneration or authority from others. These emergent phenomena suggest that social networks produce and sustain not only cohesion and cooperation but also social inequalities through structured relational patterns that inhibit cultural 'branching out' or more equal distribution of resources and of the benefits of development.

Surprisingly, few studies of social networks in resettlement conceive of networks other than as a dense, close-knit core of people - which is a network characterised by high density, or high ratio of actual ties to possible ties - and even fewer studies are critical of the potential dynamics of a close-knit network. Marx (1990), in his review of "the social worlds of refugees", argued that a core network of close-knit, multiplex relations can only be quite small and can serve a variety of unspecified needs. In contrast, he saw that a broader network of more simplex relations would be essential to complementing the support of the core network in times of need and in accessing 
new resources. He suggested that resettlers' diverse needs and objectives (e.g., finding work and everyday social support) can only be met with a combination of these types of networks. Chimhowu and Hulme (2006) studied livelihood dynamics in both planned and spontaneous resettlements in Hurungwe District, Zimbabwe from 1980 to 2000. In their analysis, they distinguished between "livelihood cells", tight-knit networks of neighbours who lived in close proximity to one another and who pooled productive resources and organised reciprocal labour pools, and "livelihood networks", which they describe as extended networks utilised by households to access information, support, guidance, and material support (Chimhowu and Hulme 2006, 730). Livelihood cells were critical to quotidian household needs, while livelihood networks proved more essential to times of crises, such as drought, which often drain the limited resources of the cell.

In their study of relations between refugees and host communities in the Buduburam camp in Ghana, Porter et al. (2008) found that close ties provided essential support in times of privation and those who lacked close kinship ties in resettlement experienced special hardships. Importantly, some youths found themselves overburdened by commitments to support kin in their close-knit networks. In a study of the 1980s "betterment" relocation programmes in Hobeni, in South Africa's Eastern Cape, Fay (2012) found that resettlers with dense networks comprised mostly of kin found the more heterogeneous resettlement community inhospitable and felt pressure to resettle again, while those with more diverse social networks became more integrated into the new community and felt far less pressure to leave. Porter et al. (2008) similarly found that those who developed social networks in the host communities generally fared better in terms of livelihood improvement, especially in terms of access to employment.

In addition to dense networks, there has been some attention to the role of bridging, in other words having unique connections across a network. Those individuals or roles that bridge can be gatekeepers, facilitators, information conduits, etc. For example, in the rural Andean highlands, social labour is mobilised through often complex systems of balanced and generalised reciprocity that are essential for meeting the subsistence needs of households. Often, key actors monopolise access to extra-community networks in the larger clientelist system of Ecuadorian politics, which provides incentives for community organising, while attracting the support of outside benefactor agencies, both state and non-governmental. Gonzalez-Parra and Simon (2008), in their study of Pehuenche resettlement in the wake of dam construction in Bio Bio, Chile, found that social networks played several critical roles in people's livelihoods and wellbeing. Women in the resettlement reported an increased sense of vulnerability because of a lack of close social ties. Importantly, they point to the emergence of powerful brokers who monopolised ties to outside agencies and resources, which they leveraged as power in community affairs. They found that these sorts of clientelistic networks fostered the development of inequality and dependency. Though strictly speaking not a network study, Halvorson and Hamilton (2007, 327), in their study of earthquake impacts in mountainous Central Asia, found women were cut off from vital networks of information pertaining to emergency services and risk management as a result of 
male transition to off-farm work. Men were more likely to form the social bridge (formally or informally) to outside institutions and their absence often left the women cut off from these sources of information. Bridging roles would serve to connect these individuals to the people and resources they need.

Finally, since many networks are an amalgamation of different types of ties and interests, it is worth understanding the extent to which there are subgroups that help form the network and whether these relatively identifiable subgroups tend to be somewhat connected to other subgroups or largely cut off from them. This is slightly different from bridging that typically is more about having unique paths to other individuals that do not necessarily form an identifiable subgroup. For example, sometimes there are political allegiances in a community, or geographically-based relationships, or kin-based subgroups.

\section{Methodology}

Social network analysis begins with a choice between studying either whole networks, personal networks, or a combination of the two types. Whole network analysis assumes a theoretically fixed boundary - such as a firm, office, or village - and elicits information from respondents about their ties to the other actors within that bounded group. The assumption for a whole network is that people from within the theoretically bounded group have a greater chance of interacting with one another than with any other random set of people outside of that group. A personal network or egocentric network is a list of people that the interviewee knows, and that list of people can vary based on the researcher's question (e.g. the people you've seen in the past year, or people you remember from childhood, or people that you trust). It is also possible, and reasonable, to attempt to connect the various people together in a personal network by asking the interviewee about the relationships between the people the interviewee named. We employed both types of network analysis during two periods of fieldwork, the first in 2009 and the second in 2011.

In 2009, we conducted a personal network analysis with a sample of respondents in both the Penipe Nuevo and Pusuca resettlements, as well as in several disaster-affected villages in the region. We sampled 100 randomly chosen households (of the possible 287 households) in Penipe Nuevo and attempted to sample all of the 45 households in Pusuca, but ended up with 41 in the latter. We randomly chose a household member over 18 years of age from each sample household for interviews. We asked respondents to name 45 people that they know by sight or name with whom they have had contact in the past two years or could have if they'd needed to. We used the same random seed with each list to arrive at a final subsample of 25 network members per respondent - using 40-60 or so as an initial list and subsampling at 20-30 is an acceptable approach for obtaining accurate structure in a personal network while reducing respondent burden (McCarty, Killworth, and Renell 2007). We asked the respondent if each of these 25 people in a personal network interacted with one another a lot, some, or none/little, producing a total of 300 or $(25 * 25-25) / 2$ possible valued non-directional ties. As part of the 
personal network survey, we asked whether each of the 25 people provided (i.e. yes/no) informational, material, emotional support, or work opportunities to the respondent and vice versa. In addition to the personal network survey, we collected data on various aspects of wellbeing and indicators of recovery.

In 2011, we conducted whole network surveys in Pusuca and with resettlers in the Penipe Nuevo resettlement and complemented these with questions about access to community resources and participation in community affairs. The whole network sample included 52 households in Penipe Nuevo that were former residents of the village of Manzano and all 40 occupied households in the Pusuca resettlement. Based upon findings from key informant interviews, we developed a list of the six most common types of exchange - prepared meals, shares of crops, cash loans, tool loans, randimpa (dyadic labour reciprocity), and peon (labour exchanged for three meals and around \$10/day). (Childcare was initially part of the list, but it was discarded because it was not a type of exchange in which each household had an equal opportunity to participate.). A randomly selected adult from each household was asked to indicate whether or not they had exchanged (given and/or received) each type of exchange in the past year with each other household in their respective samples (i.e. each household in Manzano or Pusuca). In another part of the interview, respondents were asked to name three individuals in their network that they would consult for information or opportunities with outside institutions.

The three key ratio-level variables employed in our approach to the analysis of connections between network members that we discuss here are density, bridging (average betweenness centrality), and subgroup cohesion. Density refers to the ratio of the number of observed ties to possible ties (see Figure 1). High values indicate potential constraints, conformity, and a closed group, while low values may inhibit collective action due to lack of connections. Moderate density should therefore prove sufficient to move materials and information through the network to a given actor and sustain collective action without necessarily producing cultural conformity. Bridging (often measured as average betweenness centrality) is the average of individuals' scores concerning the degree to which an individual lies along the paths that connect other network members (see Figure 2). Moderate bridging should prove more adaptive because many individuals then serve as bridges for the movement of information and materials between subgroups, but the network is not so uniformly structured as with high bridging, such that everything bridges to everyone else. The latter would eliminate cohesive subgroups that help each other or have incentive to seek novel resources. Subgroup cohesion (Alba 1973) refers to the ratio of density of ties inside a subgroup to ties between subgroup and others (see Figure 2). In a resettlement, moderately high subgroup cohesion would mean that subgroups are identifiable within the larger network, moderately high cohesion would mean that the subgroups would not be expected to fall apart if one or two people in the subgroup are removed. Nor do the subgroups become totally separated from other subgroups if one or two bridging people are removed. Such cohesive subgroups are expected to offer diversity of information and resources, 
sufficient redundancy of social ties to move information and resources between subgroups and to the interviewee as a person in need of assistance, and common interests within them.
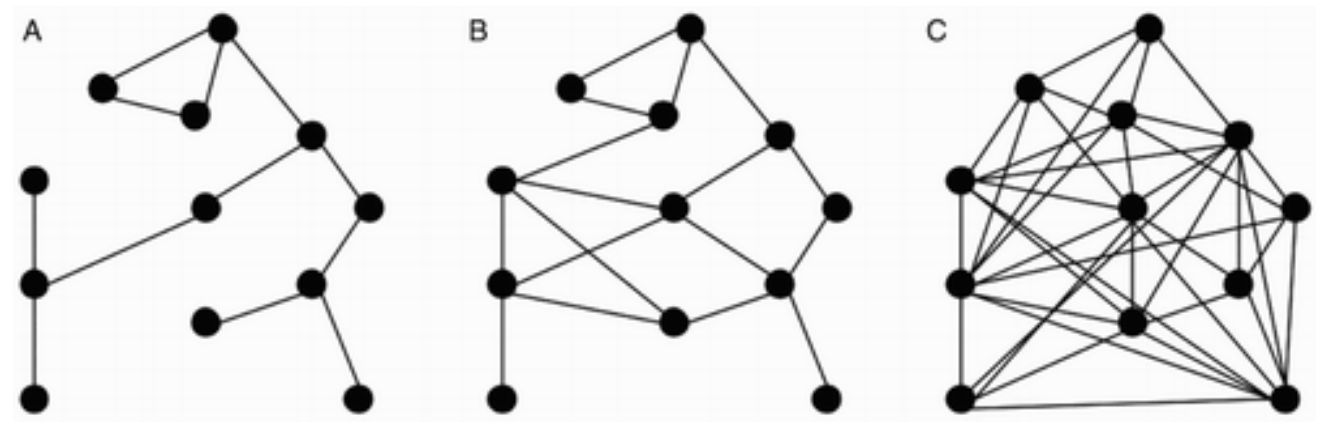

Figure 1. Network density.Note. A hypothetical network model of density. Progressing from graph A to graph $\mathrm{C}$, the ratio of possible ties to actual ties (density) increases.

A

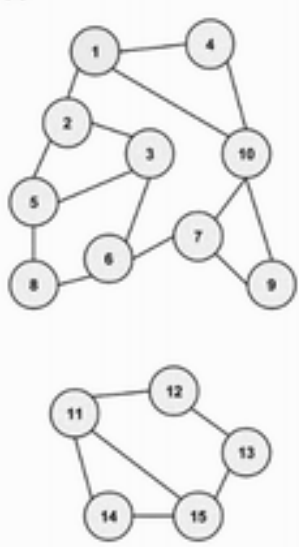

B

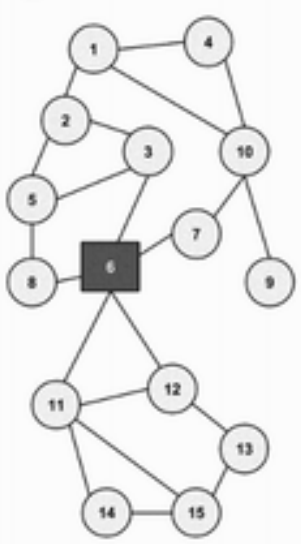

C

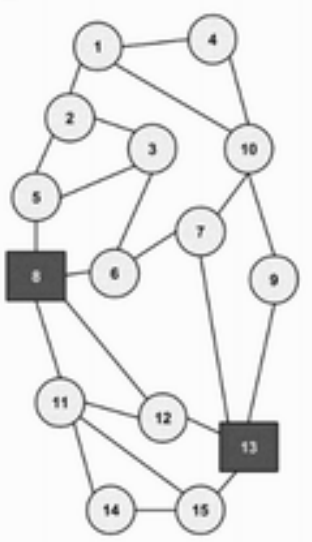

D

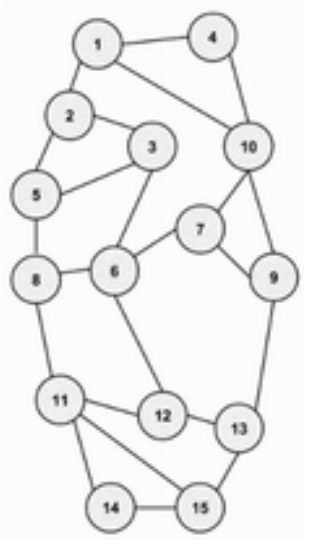

Figure 2. Network bridging and subgroup cohesion.Note. A hypothetical model of network bridging and subgroup cohesion. Progressing from graph A to graph D, we can see that graph A has no bridges between the two network subgroups. In graphs B and C, key actors bridge from one subgroup to the next (\#6 in graph B, \#8 and \#13 in graph C). In graph D, connections between the subgroups are less reliant on key bridging actors. This figure also tells a story of subgroup cohesion. In graph A, we have no connectivity, while in graph B we have connectivity but no cohesion, as the connectivity depends on one actor. Cohesion increases in graph $\mathrm{C}$, but remains relatively weak. Graph D represents moderate subgroup cohesion (after Moody and White 2003).

\section{Findings}

\section{Density}

Looking at Table 1, we can see that personal network density is positively associated with both the giving and receiving of every category of support elicited (material, information, emotional, work invitations) in the dense urban resettlement of Penipe Nuevo. In contrast, in the smaller, 
rural agricultural resettlement, network density is only associated with giving and receiving work invitations. We suggest this might be due to the fact that rural resettlers in urban resettlement, lacking productive resources, must rely more heavily on the dense networks of relationships from their prior village for material support. In the small rural resettlement, however, resettlers are less reliant on prior village contacts for support, finding support perhaps through new contacts and branching out and forming networks that are less dense.

Table 1. Correlation of personal network density in resettlements with social support exchanges.

\begin{tabular}{|l|l|l|l|l|l|l|l|l|}
\hline & $\begin{array}{l}\text { \% Alters } \\
\text { providing } \\
\text { material } \\
\text { support }\end{array}$ & $\begin{array}{l}\text { \% Alters } \\
\text { providing } \\
\text { information }\end{array}$ & $\begin{array}{l}\text { \% Alters } \\
\text { providing } \\
\text { emotional } \\
\text { support }\end{array}$ & $\begin{array}{l}\text { \% Alters } \\
\text { receiving } \\
\text { material } \\
\text { support } \\
\text { from } \\
\text { EGO }\end{array}$ & $\begin{array}{l}\text { \% Alters } \\
\text { receiving } \\
\text { information } \\
\text { from EGO }\end{array}$ & $\begin{array}{l}\text { \% Alters } \\
\text { receiving } \\
\text { emotional } \\
\text { support } \\
\text { from EGo }\end{array}$ & $\begin{array}{l}\text { \% } \\
\text { Alters } \\
\text { inviting } \\
\text { EGO to } \\
\text { work }\end{array}$ & $\begin{array}{l}\text { Alters } \\
\text { invited } \\
\text { to } \\
\text { work } \\
\text { by } \\
\text { EGO }\end{array}$ \\
\hline $\begin{array}{l}\text { Penipe } \\
\text { Nuevo }\end{array}$ & $.258^{*}$ & $.254^{*}$ & $.293^{* *}$ & $.321^{* *}$ & $.251^{*}$ & $.280^{* *}$ & $.220^{*}$ & $.272^{* *}$ \\
\hline Pusuca & .249 & .290 & .220 & .277 & .302 & .249 & $.344^{*}$ & $.410^{*}$ \\
\hline
\end{tabular}

*Correlation is significant at the 0.05 level (2-tailed).

**Correlation is significant at the 0.01 level (2-tailed).

\section{Bridging}

There are several ways to operationalise network bridging. In both personal and whole networks, we could look at individuals that bind together subgroups within the network, but it is theoretically and practically more interesting to see who has unique ties outside the network; that is, to see which individuals are most likely to connect group members to resources beyond the network. In a personal network, we could look for key individuals that provide and/or receive information, since to provide information implies that one has a non-redundant source (i.e. outside the network) for such information. In a whole network, the concept is similar. We employed both of these approaches in the resettlements in 2009 and 2011 and report many of the findings in another article (Faas et al. 2014). An analysis of personal networks found that, in Penipe Nuevo, while men were significantly more likely to receive information as a form of social support, women were significantly more likely to provide informational support. There was no such association with gender and the exchange of information in Pusuca. Yet two years later, when in a whole network interview respondents were asked whom they would consult for information or opportunities with institutions, men outnumbered women 7:1 among a subsample of resettlers in Penipe Nuevo, and 2:1 in Pusuca.

\section{Subgroup cohesion}


Subgroup cohesion can be measured in personal as well as whole networks, but to analyse this variable meaningfully one needs either a sizeable sample or rich ethnographic data to complement small samples. Our sample of 142 personal networks allows us to examine variation in subgroup cohesion, but our sample of two whole networks requires a more descriptive, ethnographic approach. Not all networks have subgroups per se. Extremely dense networks appear as one group and really sparse networks might not appear to form any group at all, structurally speaking. But when we do see subgroups, their cohesiveness is a matter of whether they are held together by one or two ties or by multiple ties.

Our analysis of personal networks in the resettlements found no association between subgroup cohesion and social support exchanges. In another publication (Jones at al. 2014), where we examine relationships between personal network structure and well-being, we found that personal networks with subgroups were associated with the best mental health in both resettled and non-resettled Mexican samples of men and women, a non-resettled Ecuadorian sample of men and women, and next to best mental health (after tight networks) for a resettled Ecuadorian sample of women. Our expectation was that subgroup cohesion in a personal network would be positively associated with well-being, since it would not be so dense as to be suffocating, not so sparse as to not be a reliable source of social support, and not entirely dependent upon key brokers that held network subgroups together.

When it came to examining subgroup cohesion in the whole networks of the resettlements, we did so ethnographically. In Pusuca, we found relatively high subgroup cohesion, as there are definite subgroups that have enough connections between them to bind them together in different ways and these ties are not dependent on a short list of key bridging actors. One key subgroup comprised an extended family and several other non-kin households, all of whom were former residents of a hacienda-cum-cooperative, El Tingo. Another sizeable subgroup was made up of former residents of the village of Pungal de Puela, which was roughly half the resettlement. There were two other smaller subgroups of extended family networks, combined with ritual kin, and still others whose villages of origin were underrepresented in the resettlement and therefore did not belong to any particular subgroup. While analysis of the whole network found that members of these subgroups were tied to others within their subgroup through multiple categories of reciprocal exchange, there were also several community institutions and practices that bound them to one another. Though reciprocal exchange patterns mostly conformed to these subgroups, there was plenty of reciprocal exchange between members of each subgroup, but not so much as to dissolve the subgroup into the larger network. Moreover, resettlers in Pusuca were tied to one another through several community institutions. All resettlers were obligated to participate in weekly cooperative labour parties (mingas) and monthly village council meetings. Most attended meetings of several committees (irrigation, potable water, childcare, agricultural extension, etc.) that met bi-weekly. The general social environment is one of low levels of trust between resettlers, who gossip unremittingly about one another's participation, but the result is actually high levels of cooperation, which is in many ways enforced by the gossip. 
In Penipe Nuevo, by contrast, we found no real subgroup cohesion. Instead, there were countless subgroups with little or no ties between them. The resettlement comprised former residents of roughly a dozen villages, most of whom were settled together in blocks in the resettlement. Because there is no land or productive resources in the resettlements, most social life, reciprocal exchange relations, and cooperation take place in the shadow of the volcano, in resettlers' villages of origin, where they return daily to tend to crops and animals. Mingas and committee meetings are organised by village councils in each respective village and, while there are parishwide governing commissions (juntas parroquiales), most of the interactions between communities are competitive, rather than cooperative. The respective villages compete for access to outside aid and development resources and, even where they seem to cooperate, as with the construction and maintenance of a parish-wide irrigation canal, villagers gossip incessantly about other villages' lack of work ethic as they compete to focus labour efforts on sections of the canal that service their respective villages. Here, the general social environment is one where gossip is trained on 'others' from other villages and there is very little dissent among residents of the same village. Although there are committees in the resettlement, they lack both power and participation because the only property is personal (the homes) and there are no productive or commonly-owned resources around which to organise (Faas in press).

\section{Discussion}

We have seen that the merits of dense, tight-knit networks may have been overstated in the literature. While such networks of social support can be important for daily survival, they appear to be relied-upon where resources in resettlement are most inadequate. In a resettlement with a more adequate resource base, such networks were not as vital and people may find themselves extending their networks, forming new relations, and working with new institutions. Of primary importance to us as researchers of development and resettlement is that density may be the result of network closure and, when closure maintains density and existing power relations in the resettlement context, it inhibits potentially adaptive innovations in culture and social practice, such as new production techniques or cooperation with outside groups or institutions.

Network bridging is often trumpeted as a source of social capital in the social network literature. This is often a source of power for those actors who do bridge beyond a given network and access or control scarce resources. Our findings here were seemingly contradictory, but not unresolvable once we explore some of the ethnographic context. In our personal network analyses in 2009, we found, in Penipe Nuevo, women providing more information through social ties and men receiving more. Yet, in 2011, in an effort to identify bridging actors in our whole network study, respondents were asked to name those in the network to whom they would turn in search of information and opportunities with outside institutions. We then found that men vastly outnumbered women as sources of this type of information.

There are at least three possible explanations for this. First, it is possible that this is a result of method bias, as our initial sample of personal networks in Penipe Nuevo was a random selection 
of all households in the resettlement, and our 2011 whole network analysis was conducted with a smaller sample of resettlers - those hailing from the village of Manzano. Second, it could simply be that networks of information flow changed drastically between 2009 and 2011. The third, and in our opinion more likely, possibility is that conditions in Penipe Nuevo were such that women indeed were more likely to receive unique information in 2009 and onward, while actual access to the resources of outside institutions was monopolised by men. This explanation echoes in many ways the findings of Halvorson and Hamilton $(2007,327)$ in their research in Central Asia in villages chronically affected by earthquakes. As in their sites, men were frequently absent from the Penipe Nuevo resettlement, tending to crops and animals in their lands in the risk zone, or working in the cities. While the men were off and the women attending to domestic chores and small, home-based businesses (e.g. stores, bakeries, seamstress, etc.), representatives from local and provincial government, as well as the resettlement agencies, NGOs, and business interests would often visit the resettlement, leaving word of upcoming events, projects, and other pieces of valuable information. This is, however, primarily a story of how information was delivered by outside sources into the village. In 2011, when asked to consider whom it is they would approach for information and opportunities with outside institutions, respondents overwhelmingly named men. This may be in large part because men continued to dominate positions of power on governing councils and committees and were therefore also more likely to be recognised as leaders and have direct, personal contact with outside institutions (see Faas et al. 2014).

We found also that a combination of pre- and post-resettlement conditions contributed to our findings regarding sub-group cohesion. Pre-resettlement patterns of kinship and village residence largely accounted for the existence - and, in the case of Penipe Nuevo, reification - of network subgroups in the resettlements. While the lack of productive and commonly held resources in Penipe Nuevo led resettlers to rely more heavily on their pre-resettlement kin and village networks for social support, the presence of these resources in Pusuca in many ways facilitated a branching out of networks for social support, coupled with a diminished reliance on preresettlement networks. Furthermore, while the newly created councils and committees were weak in Penipe Nuevo, they were strong in Pusuca for many of the same reasons - because they had a base of resources around which to organise. These overarching institutions and the resource bases facilitated cohesion between the subgroups and, in many ways, helped foster the development of informal ties of reciprocity between resettlers.

Conceivably, there are many factors to consider in network formation and practice. One thing worthy of consideration is the physical design of resettlements, although this is beyond the scope of this paper. A reasonable hypothesis would be that denser resettlements produce denser networks, while more sparse resettlements produce sparser networks. While this is conceivable in contexts other than those presented here, this is not, strictly speaking, consistent with our findings. Instead, we found that the denser urban resettlement did not foster the development of many ties between resettlers. Instead, resettlers in this village relied on the dense support 
networks of their prior villages. So, personal network density was an important factor in daily support exchanges, but these were ties fostered and sustained among residents with shared villages of origin and not between resettlers from different villages. However, as we have discussed, had institutional arrangements been different and had the Penipe Nuevo resettlement included productive and commonly managed resources, we might have seen more subgroup cohesion, or the development of ties between groups, rather than an intensification of ties within groups. Furthermore, given the comparatively small size of these resettlements (the greatest possible distance between neighbours was roughly six city blocks), it is unclear what network effects, if any, might be related to the spatial layout. In a larger resettlement than either of the two relatively small resettlements discussed this article, spatial distribution could certainly be a more significant variable worth exploring in greater depth. That said, settlement pattern depends very much on pre-existing groups/sub-groups, so care must be taken to include the types of people and types of relationships when testing for the effect of settlement pattern.

\section{Conclusion}

We have found that a systematic inquiry into the pattern of social relationships in resettlements is feasible. Each interview takes probably 45-60 minutes on average, however, so good field interviewers are crucial. We realise this is something that extensive fieldwork can also do perhaps requiring more time. Still, we have pointed to such options as subsampling for personal network analysis in the interest of reducing both researcher and respondent burden for each interview. Half of our interview was taken up by questions about each alter, so reducing these questions can reduce burden. In large resettlements, stratified sampling could provide representative personal networks to reduce the number of interviews needed for analysis of personal networks. Additionally, random sampling of the resettled community to generate a whole network by combining the lists of 45 (or whatever number chosen) also produced reliable structure and reduces the number of interviews needed for analysis of the whole network (e.g., Costenbader and Valente 2003). Data collection need not be prohibitively intensive, and ethnographic approaches equipped with this broad set of conceptual tools (i.e. network structures) might yield valuable results. Indeed, we feel that both ethnography and social network analysis are important complements to one another, especially in the context of resettlement.

With the data produced by social network analysis, we might more effectively develop interventions that provide people not only the education, training or resources, but with connections that help them adaptively react to the particular pressures posed by resettlement settings. Network approaches can prove invaluable for planning and policy-making in resettlement schemes. Studying networks from past resettlements can help inform future ones and, since a host of conditions will vary in each resettlement, we advocate the study of resettler networks through the process of resettlement because this can help inform decision-making throughout the many phases of resettlement development. While every resettlement will present unique cultural, physical, and ecological conditions that need to be considered as part of any 
analysis, building a corpus of knowledge about how networks form and actors organise various practices through them can potentially go a long way towards understanding social organisation and the social life of resettlements. Future research should consider which aspects of these and other findings are applicable to other cultures and other contexts (e.g. refugee or developmentinduced resettlement).

Social network analysis will help show where social roadblocks to equitable and effective resettlement occur. We feel that the three measures we present - density, bridging, and subgroup cohesion - form a core for a descriptive index of structure central to formulating and testing hypotheses about networks and resettlement. Where networks are dense and centralised, a majority of social actors would be constrained by in-group conformity and dependence upon a minority of social actors in positions of power over resources, means of production, and political agency. We expect, then, that resettlement will therefore be most successful when it preserves close ties including kin and friends as well as fostering new relationships and generally diversifying the network channels through which resources and information flow and power is negotiated. By referencing these network concepts, we believe that researchers and policymakers can begin to imagine network structures other than the arguably limited concept of the dense, close-knit network, while beginning also to question the purported values of such networks in different conditions. Nonetheless, we would advocate the use of focused on-the-ground ethnographic insights for any given situation in order to discern better options from among the good options suggested by the structural results.

The purposive extension of a given actor's network ties could be expected to foster an increase in the number of exchange alternatives in their network, rendering them less dependent on former, perhaps exploitative, relations. It may also have the effect of relaxing the degree to which a given actor is constrained by redundant ties to individuals with the same set of values. We say purposive extension of network ties, because tight and closed personal networks may serve a purpose when exchange alternatives are relatively absent - we have observed people living in resettlements surviving by focusing all of their efforts on their former community where their land and limited productive potential remains. In such a case, it would not make sense to push to open up their network unless that opening up involved access to new productive potential such as a communal greenhouse, land that can be rented in the resettlement, development of a marketing cooperative based in the resettlement that brings their products from the myriad villages they continue to farm in, etc. Increased integration with broader networks could result in the relaxation of social norms and increased social, political, and economic diversity in the establishment and growth of a resettlement over time. Used carefully, we find that a network approach operationalises the challenges and the potential of a more equitable distribution of resources, social possibilities and rights in resettlement.

This study introduces resettlement research to systematic social network analysis, and in this paper we have begun to review the relevant policy applications of a social network approach particularly since network applications to resettlement have not been developed in the literature. 
However, some basic principles can be suggested. For example, the 'land for land' compensation provision in the World Bank's most recent operational policy on land-based resettlement has already been criticised elsewhere for merely attempting to recreate prior standards of living and not extending land rights to the long-term landless and even those that have been recently separately from their land. A network approach reinforces this argument by making plain the patterns of dependency whereby unequal access to resources and the means of production constrains group recovery and adaptation to resettlement - suggesting the need to extend land rights to the formerly landless as well as those holding title to land, and certainly not permanently ensure or increase inequality. But the approach goes further to suggest that the longterm success of planned resettlements can be realised by identifying dense network clusters, patterns of group centralisation, and the resources controlled by actors in bridging positions. These bridges are not unlike bottlenecks along paths to wider social structures via ties with state institutions, distributors of production and consumption goods, and those disseminating public information. The tendency typically is to increase dependency via connections with peripheral actors, but specific efforts could be made to mitigate how those patterns of increased engagement play out.

There are a variety of applications of this approach. Integration can take the form of inclusion in planning committees and local cooperatives, thus going beyond existing leadership to select representatives from the less-represented groups and individuals in resettlement communities. Leadership by less wealthy members is one way to maintain mutually beneficial collective action even when resource distribution may be numerically unequal (Jones 2004). Potentially adaptive innovations in culture and social practice, such as new production techniques and cooperation with outside groups or institutions, can be fostered by connecting labourers and agricultural producers to each other and to related economic and agricultural initiatives. New education and employment opportunities for youth and adults alike can also foster new ties. However, as with all applied research, there may be drawbacks. We imagine that fostering or supporting the development of new networks may also cause social strain, since it challenges the tendency of most all relocatees to revert to traditional patterns of reciprocity and patronage, even if those patterns reinforce inequality or relatively low access to resources and information.

\section{Acknowledgements}

The authors would like to thank Michael Cernea for comments on an earlier draft of this paper, presented at the 68th Annual Meeting of the Society for Applied Anthropology in Memphis, TN, 24 March 2008. The research drawn upon for this article was partially funded by the National Science Foundation (NSF 0751264/0751265, Collaborative Research - Social Networks in Chronic Disasters: Exposure, Evacuation, and Resettlement, A National Science Foundation Dissertation Improvement Grant (NSF \#1123962), and the Fellowship in Hazards, Risk, and Disasters (PERISHIP), a joint program of The Natural Hazards Center at the University of Colorado and the Public Entity Risk Institute (PERI) with funding from the National Science Foundation. 


\section{References}

1. Alba, R. D. 1973. "A Graph-Theoretic Definition of a Sociometric Clique." The Journal of Mathematical Sociology 3: 113-126. doi:10.1080/0022250X.1973.9989826

2. Behura, N. K., and P. K. Nayak. 1993. "Involuntary Displacement and the Changing Frontiers of Kinship: A Study of Resettlement in Orissa." In Anthropological Approaches to Resettlement: Policy, Practice, and Theory, edited by S. Guggenheim and M. Cernea, 283-306. Oxford: Westview.

3. Cernea, M. 1996. "Bridging the Research Divide: Studying Refugees \& Development Oustees." In In Search of Cool Ground: War, Flight and Homecoming in Northeast Africa, edited by T. Allen, 293-317. Geneva: United Nations Research Institute.

4. Cernea, M. 1997. "The Risks and Reconstruction Model for Resettling Displaced Populations." World Development 25 (10): 1569-1587. doi:10.1016/S0305-750X(97)00054-5

5. Cernea, M. 2003. "For a New Economics of Resettlement: A Sociological Critique of the Compensation Principle." International Social Science Journal 55 (185): 37-45.

doi:10.1111/1468-2451.5501004 6. Chimhowu, A., and D. Hulme. 2006. "Livelihood Dynamics in Planned and Spontaneous Resettlement in Zimbabwe: Converging and vulnerable." World Development 34 (4): 728-750. doi:10.1016/j.worlddev.2005.08.011

7. Costenbader, E., and T. W. Valente. 2003. "The Stability of Centrality Measures when Networks are Sampled.” Social Networks25: 283-307. doi:10.1016/S0378-8733(03)00012-1

8. Faas, A. J. 2012. "Reciprocity and Development in Disaster-Induced Resettlements in Andean Ecuador." Unpublished Doctoral Dissertation. Department of Anthropology, University of South Florida.

9. Faas, A. J. In press. "Disaster Resettlement Organizations, NGOs, and the Culture of Cooperative Labor in the Ecuadorian Andes." In Disaster's Impact on Livelihoods and Cultural Survival: Losses, Opportunities, and Mitigation, edited by Michele Companion. Boca Raton, FL: CRC Press.

10. Faas, A. J., E. C. Jones, L. M. Whiteford, G. A. Tobin, and A. D. Murphy. 2014. Gendered Paths to Formal and Informal Resources in Post-Disaster Development in the Ecuadorian Andes. Mountain Research and Development 34 (3): 233-234. doi:10.1659/MRD-JOURNALD-13-00100

11. Fay, D. A. 2012. “'The Trust is Over! We Want to Plough!': Social Differentiation and the Reversal of Resettlement in South Africa." Human Ecology 40: 59-68. doi:10.1007/s10745-0119452-5 
12. González-Parra, C., and J. Simon. 2008. "All That Glitters Is Not Gold: Resettlement, Vulnerability, and Social Exclusion in the Pehuenche Community Ayin Mapu, Chile." American Behavioral Scientist 51 (12): 1774-1789. doi:10.1177/0002764208318930

13. Halvorson, S. J., and J. P. Hamilton. 2007. "Vulnerability and the Erosion of Seismic Culture in Mountainous Central Asia."Mountain Research and Development 27 (4): 322-330. doi: $10.1659 / \mathrm{mrd} .0900$

14. Jones, E. C. 2004. "Wealth-Based Trust and the Development of Collective Action." World Development 32 (4): 691-711. doi:10.1016/j.worlddev.2003.10.009

15. Jones, E. C., G. A. Tobin, C. McCarty, A. J. Faas, H. Yepes, L. M. Whiteford, and A. D. Murphy. 2014. "Gender, Social Support and Well-Being in Acute Disasters, Chronic Hazards, and Resettlements: The Cases of Mexico, Ecuador and the United States." In Issues of Gender and Sexual Orientation in Humanitarian Emergencies, edited by Larry Roeder, 50-119. New York: Springer.

16. Marx, E. 1990. "The Social World of Refugees: A Conceptual Framework.” Journal for Refugee Studies 3 (3): 189-203. doi:10.1093/jrs/3.3.189

17. McCarty, C., P. D. Killworth, and J. Renell. 2007. "Impact of Methods for Reducing Respondent Burden on Personal Network Structure Measures.” Social Networks 29: 300-315. doi:10.1016/j.socnet.2006.12.005

18. Moody, J., and D. R. White. 2003. "Structural Cohesion and Embeddedness: A Hierarchical Concept of Social Groups."American Sociological Review 68: 103-127. doi:10.2307/3088904

19. Porter, G., K. Hampshire, P. Kye, M. Adjaloo, G. Rapoo, and K. Kilpatrick. 2008. 'Linkages between Livelihood Opportunities and Refugee-Host Relations: Learning from the Experiences of Liberian Camp-based Refugees in Ghana." Journal of Refugee Studies 21 (2): 230-252. doi:10.1093/jrs/fen015 